\title{
Mechanism of Resistance to Oxidative Stress in Doxorubicin Resistant Cells
}

\author{
Shinobu Furusawa, ${ }^{*, a}$ Etsuko Kimura,${ }^{a}$ Satoko Kisara, ${ }^{a}$ Shinya Nakano, ${ }^{a}$ Ryo Murata,,${ }^{b}$ \\ Yorihisa TANaKa, ${ }^{b}$ Shuhei SAKaguchi, ${ }^{c}$ Motoaki Takayanagi, ${ }^{a}$ Yoshio Takayanagi, ${ }^{a}$ and \\ Ken-ichi SASAKI ${ }^{a}$ \\ Department of Pharmacology and Toxicology, Cancer Research Institute ${ }^{a}$ and First Department of Pharmaceutics, ${ }^{b}$ First \\ Department of Hygienic Chemistry, ${ }^{c}$ Tohoku Pharmaceutical University, 4-4-1 Komatsushima, Aoba-ku, Sendai \\ 981-8558, Japan. Received September 1, 2000; accepted January 17, 2001
}

\begin{abstract}
Doxorubicin (DOX) is an anthracycline drug widely used in chemotherapy for cancer patients, but it often gives rise to multidrug resistance in cancer cells. The purpose of this work was to study the effect of hydrogen peroxide in DOX-sensitive mouse P388/S leukemia cells and in the DOX-resistant cell line. Hydrogen peroxide induced a significant increase in dose- and time-response cell death in cultured P388/S cells. The degree of cell death in P388/DOX cells induced by hydrogen peroxide was less than that in P388/S cells treated with hydrogen peroxide. Parent cells exposed to 3 mm of hydrogen peroxide showed a loss of mitochondrial membrane potential correlated with cell death. Hydrogen peroxide at a concentration greater than $0.3 \mathrm{~mm}$ increased the intracellular $\mathrm{Ca}^{2+}$ of $\mathrm{P388} / \mathrm{S}$ cells dose-dependently; however, no change following addition of hydrogen peroxide $(0.3-1 \mathrm{~mm})$ was observed in the resistant cells. Hydrogen peroxide $(0.1$ and $1 \mathrm{~mm})$ treatment also induced the production of intracellular ROS in P388/S cells, while no such increase was produced by this substance in P388/DOX cells. Resistant cells also showed a significant level of glutathione (GSH) compared with the parent cells. In addition, $N$ acetyl-L-cysteine and reduced GSH antioxidants abolished death of $\mathrm{P388} / \mathrm{S}$ cells caused by hydrogen peroxide. Therefore, it is believed that the reduced effect of oxidative stress towards the resistant cells may be related to an increase in intracellular GSH level.
\end{abstract} tathione

Key words hydrogen peroxide; DOX-resistant cell line; cell death; mitochondrial membrane potential; intracellular $\mathrm{Ca}^{2+}$; glu-

Acquired drug resistance to anthracyclins is associated with cross-resistance to a large number of compounds that are chemically unrelated. This phenomenon, multidrug resistance (MDR), is associated with overexpression of a membrane protein (P-glycoprotein, P-gp) as well as other factors. ${ }^{1)}$ A direct role for P-gp, a member of the ATP-binding cassette $(\mathrm{ABC})$ transporter superfamily has been suggested in the efflux of chemotherapeutic drugs from tumor cells. ${ }^{2-4)}$ Moreover, P-gp is expressed in many other internal organs and thought to play an important role in the human body. ${ }^{5}$

Reactive oxygen species (ROS) including hydrogen peroxide have been implicated as mediators of apoptosis. ${ }^{6,7)}$ While a high degree of oxidative stress can cause necrosis, low levels will trigger apoptosis. In addition, increased ROS levels have been detected emanating from apoptotic cells, and antioxidants can block apoptosis in a variety of systems. ${ }^{8,9}$ The production of potent oxidizing species, including the hydroxy radical $(\cdot \mathrm{OH})$, has recently been demonstrated during the treatment of cancer cells with doxorubicin (DOX). ${ }^{10,11)}$ Furthermore, resistance to the cytotoxic effect of DOX in this cell line apparently involves, at least in part, a significant enhancement of intracellular antioxidant defense enzymes. ${ }^{12)}$ Thus, accumulating evidence strongly suggests that ROS metabolism might play a role in the antineoplastic action on the anticancer drugs.

In this study, we investigated the cytotoxic mechanism of the hydrogen peroxide-induced oxidative stress in DOXsensitive mouse P388 leukemia cells and -resistant P-gpoverexpressing cell line.

\section{MATERIALS AND METHODS}

Materials Hydrogen peroxide, propidium iodide (PI), sulphosalicyclic acid, $d i$-sodium dihydrogen ethylenediamine tetraacetate dihydrate ( $\left.\mathrm{Na}_{2} \mathrm{EDTA}\right), 5,5^{\prime}$-dithiobis (2-nitrobenzoic acid) (DTNB), dimethyl sulfoxide, and $N$-acethyl-L-cysteine (NAC) were obtained from Nacalai Tesque, Inc., Kyoto, Japan. DOX was supplied by Kyowa Hakko Kogyo Chemical Co., Tokyo, Japan. Reduced glutathione (GSH) and $\beta$-nicotinamide adenine dinucleotide phosphate $4 \mathrm{Na}$ salt (NADPH) was purchased from Kohjin Co., Ltd., Tokyo, Japan, and Fluo 3-AM was obtained from Wako Pure Chemical Industries, Ltd., Osaka, Japan. Rhodamine 123, GSH reductase, and trypan blue were purchased from Sigma Chemical Co., St. Louis, MO, U.S.A. Monochlorbimane $(\mathrm{mBCl})$ and $2^{\prime}, 7^{\prime}-$ dichlorofluorescein diacetate (DCFH-DA) were obtained from Molecular Probes, Inc., Oregon, U.S.A., and RPMI 1640 culture medium, supplemented with 5\% glutamine, was purchased from Sigma Chemical Co., St. Louis, MO, U.S.A. Penicillin and streptomycin were obtained from Meiji Seika Co., Ltd., Tokyo, Japan. Heat-inactivated fetal bovine serum (FBS) was purchased from JRH Biosciences, Lenexa, KS, U.S.A., and Falcon tissue culture flasks $\left(75\right.$ and $\left.175 \mathrm{~cm}^{2}\right)$ were obtained from Becton Dickinson Labware, Meylan Cedex, France.

Cell Lines and Culture Mouse leukemic P388 (P388/S) cells were kindly supplied by the Japanese Cancer Research Resource Bank (Tokyo, Japan). The DOX-resistant P388 cell line (P388/DOX) was developed from parent cells by growing them in progressively increasing concentrations of a drug. The P388/DOX cells were approximately 40 -fold more resistant to DOX than sensitive cells. Cells were maintained 
in RPMI 1640 medium containing 10\% heat-inactivated FBS, 100 units $/ \mathrm{ml}$ of penicillin and $100 \mu \mathrm{g} / \mathrm{ml}$ of streptomycin and were incubated at $37^{\circ} \mathrm{C}$ in an atmosphere of $5 \%$ $\mathrm{CO}_{2}$ in air.

Detection of Cell Death Cell number was determined by trypan blue staining or counting using a Coulter model Z1 (Coulter Inc., Hialeah, FL, U.S.A.). Cells were seeded at a density of $1 \times 10^{6} / \mathrm{ml}$ in a Falcon tube and incubated with RPMI 1640 containing 10\% FBS and antibiotics in the presence of various concentrations of hydrogen peroxide at $37^{\circ} \mathrm{C}$. Then, to detect apoptotic nuclei, cell death was measured by flow cytometry (FACScan, Becton Dickinson, Tokyo) with $5 \mu \mathrm{g} / \mathrm{ml}$ PI and analyzed using Cell Quest software. ${ }^{13)}$

Calcium Measurement For monitoring intracellular calcium, cells were loaded with $1 \mu \mathrm{M}$ fluo $3-\mathrm{AM}\left(\mathrm{Ca}^{2+}\right.$ probe $)$ in a HBS buffer (140 mM NaCl, $5 \mathrm{~mm} \mathrm{KCl,} 2 \mathrm{~mm} \mathrm{CaCl}, 1 \mathrm{~mm}$ $\mathrm{MgCl}_{2}, 10 \mathrm{~mm}$ glucose and $10 \mathrm{~mm}$ HEPES, pH 7.4). After a loading period of $30 \mathrm{~min}$, excess dye was removed by centrifugation, the cells were resuspended in fresh buffer and the cell associated-fluo 3-AM fluorescence was measured with FACScan. ${ }^{14)}$

Measurement of Mitochondrial Membrane Potential Cells $\left(1 \times 10^{6} / \mathrm{ml}\right)$ were incubated with hydrogen peroxide for $0.5-4 \mathrm{~h}$. They were then rinsed once with Hank's balanced salt solution, and incubated in Hank's balanced salt solution with $2 \mu \mathrm{M}$ rhodamine 123 at $37^{\circ} \mathrm{C}$ for $30 \mathrm{~min}$. Mean intracellular rhodamine 123 fluorescence was measured by FACScan. ${ }^{15)}$ Rhodamine 123 accumulation in cells has been shown to correlate quantitatively with mitochondrial membrane potential.

GSH Assay Flow cytometric and enzymatic assays were performed in parallel and in triplicate. Flow cytometry: Monochlorobimane (mBCl, final concentration: $50 \mu \mathrm{M}$, Molecular Probes, Inc., Eugene, OR, U.S.A.) was added to P388/S or P388/DOX cells $\left(5 \times 10^{5}\right.$ cells $\left./ \mathrm{ml}\right)$ and incubated at room temperature for $5 \mathrm{~min}$. Then cells were washed twice with ice-cold phosphate-buffered saline (PBS). One milliliter of PBS was added and cellular GSH analysis was performed by flow cytometry. ${ }^{16)}$ Enzymatic assay: Total GSH (reduced+ oxidized) was determined enzymatically according to the method of Tietze. ${ }^{17)}$ Cells were collected by centrifugation, washed twice with ice-cold PBS, and sonicated in $10 \mathrm{~mm}$ $\mathrm{HCl}$. Particulate matter was removed by centrifugation $(12000 \times \boldsymbol{g}, 5 \mathrm{~min})$ and the supernatant deproteinized by the addition of $10 \%$ sulphosalicylic acid. Following recentrifugation the GSH content of the supernatant $(20 \mu \mathrm{l})$ was assayed using $0.6 \mathrm{~mm}$ DTNB in a GSH-reducing buffer $(4.4 \mathrm{~mm}$ $\mathrm{Na}_{2}$ EDTA, $250 \mu \mathrm{M}$ NADPH, $6 \mathrm{U} / \mathrm{ml}$ GSH reductase, in sodium phosphate buffer, $\mathrm{pH}$ 7.5). GSH concentration was determined spectrophotometrically at $412 \mathrm{~nm}$. Standard GSH solutions were used on each occasion to calibrate the assay. $\mathrm{GSH}$ is expressed in nmol GSH/mg protein. Protein content was determined using Pierce BCA protein assay reagents as described by Smith et al. ${ }^{18)}$ with bovine serum albumin as the standard.

ROS Assay DCFH-DA (final concentration: $5 \mu \mathrm{M}$ ) was added to $5 \times 10^{5}$ cells $/ \mathrm{ml}$, and incubated at $37^{\circ} \mathrm{C}$ for $30 \mathrm{~min}$. During this period, DCFH-DA entered the tumor cells. The treated tumor cells were exposed to DOX for $30 \mathrm{~min}$ or to hydrogen peroxide for $10 \mathrm{~min}$ at $37^{\circ} \mathrm{C}$. Fluorescence intensity

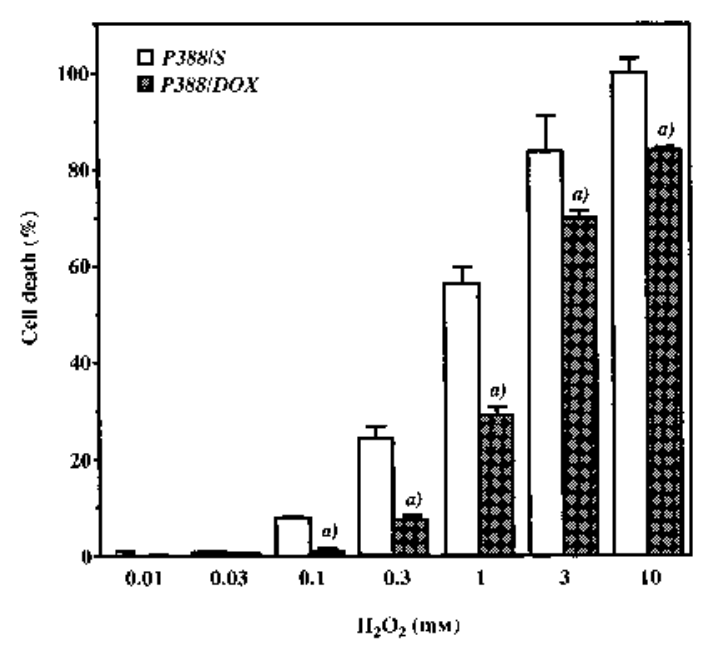

Fig. 1. Cytotoxic Response of P388 Leukemia Cells Challenged with Hydrogen Peroxide

Doxorubicin (DOX)-sensitive P388 (P388/S) and -resistant P388 (P388/DOX) cells were exposed to hydrogen peroxide $(0.01-10 \mathrm{~mm})$ for $4 \mathrm{~h}$ at $37^{\circ} \mathrm{C}$ and then stained with propidium iodide (PI) before flow cytometric analysis. Each column represents the mean \pm S.E. of three experiments. a) $p<0.05$, in comparison with $\mathrm{P} 388 / \mathrm{S}$ cells.

Table 1. Inhibition of Hydrogen Peroxide-Induced Cell Death by Antioxidant

\begin{tabular}{lcc}
\hline \hline \multicolumn{1}{c}{ Drug } & Cell death (\%) & Inhibition (\%) \\
\hline $1 \mathrm{mM} \mathrm{H}_{2} \mathrm{O}_{2}$ & $57.1 \pm 3.7$ & 0 \\
$10 \mathrm{mM} \mathrm{NAC}^{2} 1 \mathrm{mM} \mathrm{H}_{2} \mathrm{O}_{2}$ & $34.2 \pm 5.4^{a)}$ & 40.1 \\
$5 \mathrm{~mm} \mathrm{GSH}$ (reduced) $+1 \mathrm{mM} \mathrm{H}_{2} \mathrm{O}_{2}$ & $34.9 \pm 2.2^{a)}$ & 38.9 \\
\hline
\end{tabular}

P388/S cells were exposed to $1 \mathrm{~mm}$ hydrogen peroxide in the presence or absence of antioxidant for $4 \mathrm{~h}$ at $37^{\circ} \mathrm{C}$, then were stained with PI before flow cytometric analysis. Data are the means \pm S.E. of three experiments. a) $p<0.05$, in comparison with $1 \mathrm{~mm}$ hydrogen peroxide-induced treated cells.

of $2^{\prime}, 7^{\prime}$-dichlorofluorescein (DCF), DCFH-DA products, was measured by flow cytometry directly. ${ }^{19)}$

Statistical Analysis Student's $t$-test was used evaluate the statistical significance of differences between groups.

\section{RESULTS}

Cell Death Cell death induced by hydrogen peroxide was investigated in P388/S and P388/DOX cells using flow cytometry. Various concentrations of hydrogen peroxide were added to the growth medium and incubated for $4 \mathrm{~h}$. In the parent cells, hydrogen peroxide $(1,3$, and $10 \mathrm{~mm})$ resulted in a marked increase in cell death $(57.1,83.5$, and 98.6\%) compared with resistant cells (cell death: 29.2, 70.0, and 83.7\%, Fig. 1). Thus, a significant dose-dependent increase in cell death by hydrogen peroxide was observed in P388/S cells. The degree of cell death in P388/DOX cells induced by hydrogen peroxide was less than that in P388/S cells treated with hydrogen peroxide.

NAC and reduced GSH (antioxidants) also abolished the death of P388/S cells caused by hydrogen peroxide ( $4 \mathrm{~h}$-drug exposure). The inhibitory effects of $10 \mathrm{~mm}$ NAC and $5 \mathrm{~mm}$ reduced GSH on $1 \mathrm{~mm}$ hydrogen peroxide-induced cell death were $40.1 \%$ and $38.9 \%$, respectively (Table 1 ). The GSH content of resistant cells was about 1.5-fold greater than the parent cell line (Figs. 2A, B). In the study of time course ex- 

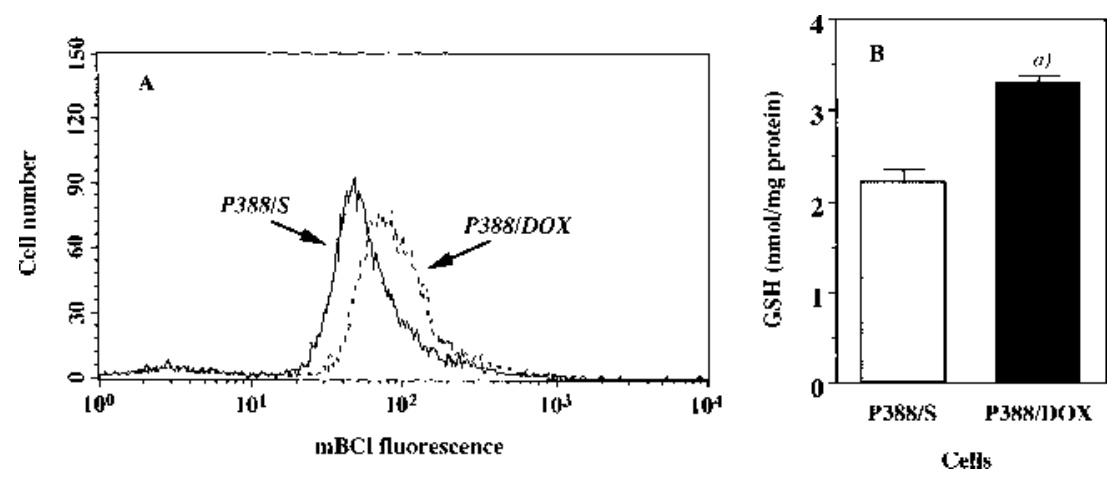

Fig. 2. Cellular Glutathione (GSH) Levels in P388/S and P388/DOX Cells

A: Cellular GSH content was measured by flow cytometry using $\mathrm{mBCl}$. B: Total GSH (reduced+oxidized) was determined by the DTNB-GSH reductase recycling assay. $a$ ) $p<0.05$, in comparison with $\mathrm{P} 388 / \mathrm{S}$ cells.
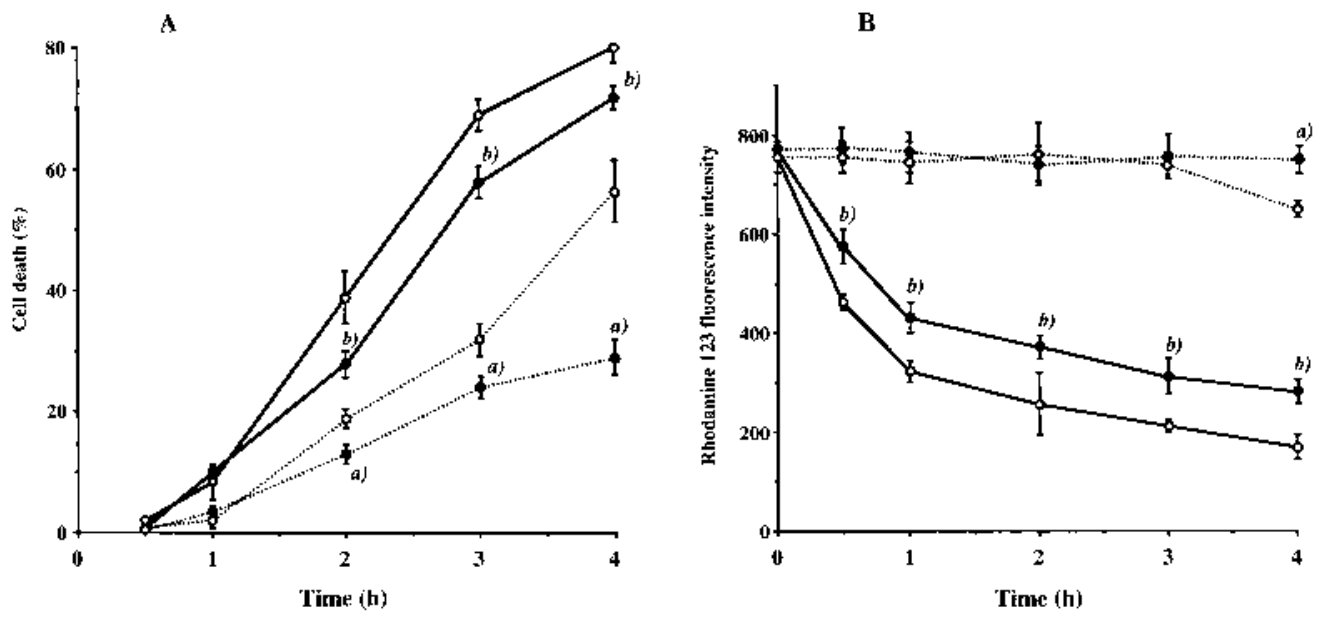

Fig. 3. Cell Death (A) and Mitochondrial Membrane Potential (B) in P388/S and P388/DOX Cells Induced by Hydrogen Peroxide

P388/S (O) and P388/DOX $(\bullet)$ cells were exposed to hydrogen peroxide $1 \mathrm{~mm}(\cdots)$ and $3 \mathrm{~mm}(-)$ for $0.5-4 \mathrm{~h}$ at $37^{\circ} \mathrm{C}$, then cell death was measured by flow cytometry with 5 $\mu \mathrm{g} / \mathrm{ml}$ PI. Mitochondrial membrane potential (fluorescence intensity of intracellular rhodamine 123) was determined as in Material and Methods. Each symbol and bar, respectively, indicates the means \pm S.E. of three experiments. a) $p<0.05$, versus $\mathrm{P} 388 / \mathrm{S}$ cells treated with 1 mu hydrogen peroxide. $b$ ) $p<0.05$, versus $\mathrm{P} 388 / \mathrm{S}$ cells treated with $3 \mathrm{~mm}$ hydrogen peroxide.

periments, hydrogen peroxide at a concentration of 1 or $3 \mathrm{~mm}$ induced death in P388/S and P388/DOX cells in a time-dependent manner (Fig. 3A). Moreover, a prolonged exposure of P388/S cells to hydrogen peroxide at a concentration of $3 \mathrm{~mm}$ produced a great decrease in the rhodamine 123 fluorescence in cells (Fig. 3B). The degree of this decrease in P388/DOX cells by hydrogen peroxide was less than that in P388/S cells treated with hydrogen peroxide. The reduction of rhodamine 123 fluorescence caused by $3 \mathrm{~mm}$ hydrogen peroxide was occurred before cell death. Treatment of hydrogen peroxide at a concentration of $1 \mathrm{~mm}$, however, did not induce a decrease in the rhodamine 123 fluorescence in cells.

Intracellular $\mathrm{Ca}^{2+}$ The dose-dependent effect of hydrogen peroxide on the intracellular $\mathrm{Ca}^{2+}$ was examined $90 \mathrm{~min}$ after application of hydrogen at concentrations ranging from 0.01-1 mm (Fig. 4A). Hydrogen peroxide in P388/S cells began to increase the intracellular $\mathrm{Ca}^{2+}$ at a concentration of $0.1 \mathrm{~mm}$. This increase produced a further increase in the $\mathrm{Ca}^{2+}$ of P388/S cells. Drastic increases in the $\mathrm{Ca}^{2+}$ were detected at 0.3 and $1 \mathrm{~mm}$, while no such increase in the $\mathrm{Ca}^{2+}$ induced by hydrogen peroxide was observed in the resistant cells (Figs. 4A, B).

ROS Seeking correlations between the sensitivity to hy- drogen peroxide observed in the cell line studies and levels of ROS, we measured the intracellular generation of ROS by leukemia using a DCFH-DA probe. Figure 5 shows the intracellular concentration of ROS in DOX-treated cell cultures determined by the flow cytometry of fluorescence emitted due to DCH oxidation. The results show that DOX increased endogenous level of ROS at $1 \mu \mathrm{M}$ doses in P388/S cells. In contrast to these cells, P388/DOX cells did not exhibit such change in intracellular generation of ROS by $1 \mu \mathrm{m}$ DOX. Hydrogen peroxide $(0.1$ and $1 \mathrm{~mm})$ treatment also induced the production of ROS in P388/S cells, while no such increase was produced by hydrogen peroxide in P388/DOX cells (Fig. 6). These results suggest that the reduction of hydroxyl radicals produced by hydrogen peroxide may be involved in the resistance to oxidative stress in the resistant cells.

\section{DISCUSSION}

Hydrogen peroxide is known to modulate a variety of cell functions, and its lower biological reactivity compared to many ROS, combined with its capacity to cross membranes and disseminate from the site of generation, makes it an ideal signaling molecule. ${ }^{20)}$ DOX is reported to cause apoptosis 
A

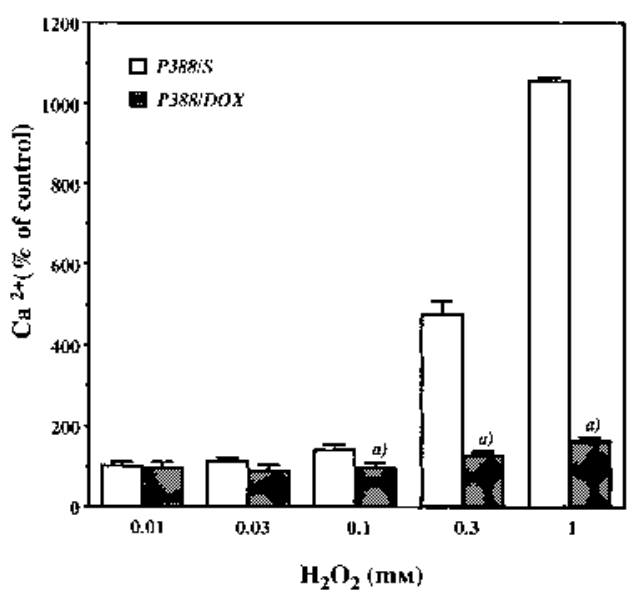

B

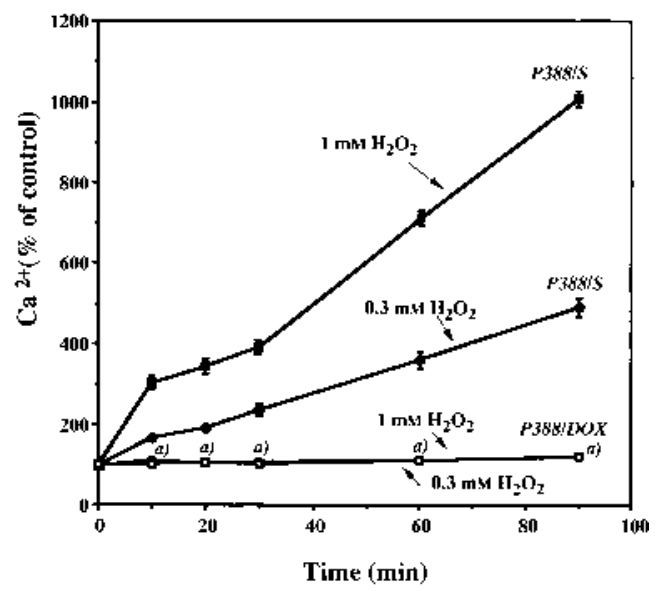

Fig. 4. Dose- and Time-Dependent Effects of Hydrogen Peroxide on the Concentration of Intracellular Ca ${ }^{2+}$ in P388/S and P388/DOX Cells

Dose-dependent effects were examined at $90 \mathrm{~min}$ after application of hydrogen peroxide at respective concentrations. Data are the means \pm S.E. of three experiments. $a$ ) $p<0.05$, in comparison with $\mathrm{P} 388 / \mathrm{S}$ cells.
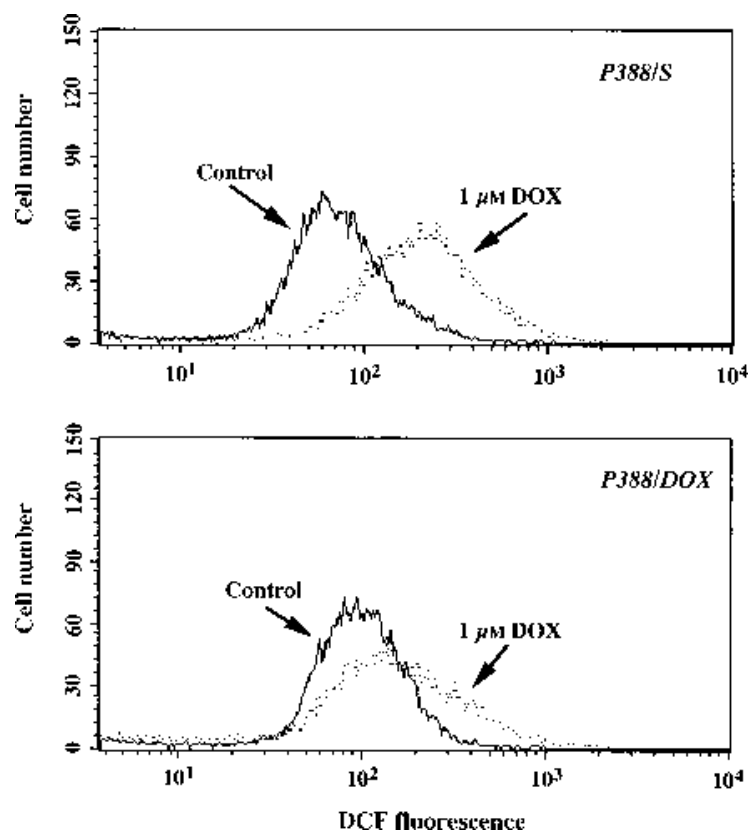

Fig. 5. Induction of Reactive Oxygen Species (ROS) by DOX in P388/S and P388/DOX Cells

The cells were preincubated with $5 \mu \mathrm{M}$ DCFH-DA for $30 \mathrm{~min}$; DOX $(1 \mu \mathrm{M})$ was added, and the fluorescence of $2^{\prime}, 7^{\prime}$-dichorofluorescein (DCF) in cells was determined on FACScan 30 min later.

and is also believed to be related to ROS generation. ${ }^{21)} \mathrm{Al}-$ though the molecular mechanism of MDR cells such as DOX-resistant cells is not completely understood, it is thought that $\mathrm{P}-\mathrm{gp}^{2-4)}$ or the multidrug resistant protein (MRP), ${ }^{22,23)}$ the $\mathrm{ABC}$ transporter superfamily member appeared in MDR cells. In this study, we investigated the mechanism of hydrogen peroxide-induced cell death in DOX-sensitive mouse P388/S leukemia cells and in the P-gp-overexpressing cell line ${ }^{24,25)}$ (P388/DOX). Hydrogen peroxide markedly induced death of the parent cells in a dose- and time-dependent manner. The degree of cell death in P388/DOX cells induced by hydrogen peroxide was less than that in P388/S cells treated with hydrogen peroxide. Although apoptosis and necrosis are morphologically distinct
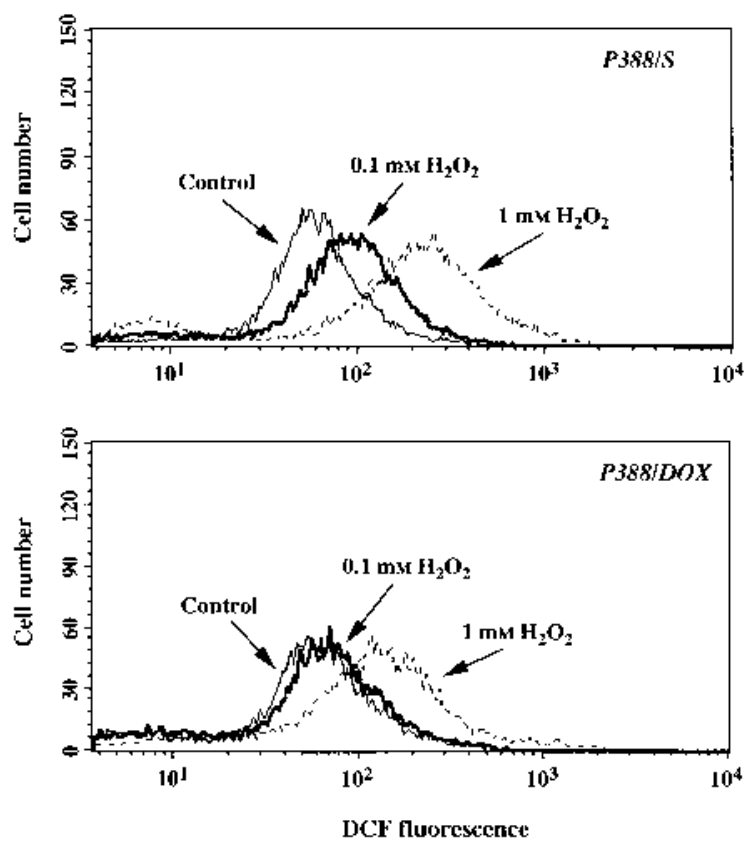

Fig. 6. Induction of ROS by Hydrogen Peroxide in P388/S and P388/DOX Cells

The cells were preincubated with $5 \mu \mathrm{M}$ DCFH-DA for $30 \mathrm{~min}$; hydrogen peroxide $(0.1$ and $1 \mathrm{mM})$ was added, and the fluorescence of DCF in cells was determined on FACScan 10 min later.

manifestations of cell death, they tend to share common features in the death signaling pathway involving functional steps of death-driving interleukin $1 \beta$-converting enzyme family proteases and anti-cell death protein $\mathrm{Bcl}-2{ }^{26)} \mathrm{Bcl}-2$ family proteins and mitochondrial dysfunction are probably key regulators of the apoptotic response. Cook et al. ${ }^{27)}$ suggested that the regulation of Bcl-2 and mitochondrial function is an important factor in oxidative stress-induced cardiac myocyte apoptosis. Bcl-2 family proteins block cell death by inhibiting disruption of the mitochondrial membrane. ${ }^{28)}$ Our results showed that an exposure of hydrogen peroxide (3 $\mathrm{mm})$ to $\mathrm{P} 388 / \mathrm{S}$ cells resulted in a loss of mitochondrial membrane potential. This loss was prior to hydrogen peroxide-induced cell death. Furthermore, the degree in loss of mitochondrial 
membrane potential from P388/DOX cells produced by $3 \mathrm{~mm}$ hydrogen peroxide was less than that in P388/S cells treated with hydrogen peroxide. These findings indicate that the resistant cells may protect against hydrogen peroxide $(3 \mathrm{mM})$ induced mitochondrial damage in cells. On the other hand, treatment ( $3 \mathrm{~h}$-drug exposure) of hydrogen peroxide at a concentration of $1 \mathrm{~mm}$ did not induce a loss in mitochondrial membrane potential in P388/S cells. Therefore, there is a possibility that the pathway in cell death induced by $1 \mathrm{~mm}$ hydrogen peroxide is not accompanied by a change of mitochondrial membrane potential.

GSH is considered to be an important mediator of cancer cell resistance to anticancer agents-based chemotherapy. Known mechanisms of MDR are an increased detoxification of compounds mediated by GSH or GSH related enzymes. ${ }^{29)}$ $M R P 1$ appeared to transport drugs conjugated to GSH and also unmodified cytostatic agents in the presence of $\mathrm{GSH}^{30}{ }^{30}$ The relation between MRP1, GSH and enzymes involved in GSH metabolism or GSH dependent detoxification reactions recently has drawn a lot of attention. In this study, the resistant cells also showed a marked level of GSH compared to the sensitive cells. NAC and GSH, which are known as scavengers, ${ }^{31)}$ abolished cell death in P388/S cells treated with hydrogen peroxide. These results suggest that GSH in the resistant cells is closely connected to the hydrogen peroxide-induced oxidative stress which exerts an effect on redox reactions.

It is likely that oxidative stress in mammalian cells induces an increase in the intracellular concentration of $\mathrm{Ca}^{2+}\left[\mathrm{Ca}^{2+}\right]_{\mathrm{i}}$, a process that is proposed to be largely responsible for subsequent cell death or injury. ${ }^{32,33)}$ It is possible that hydrogen peroxide increases $\left[\mathrm{Ca}^{2+}\right]_{\mathrm{i}}$ by altering the activity of ion channels and/or transport proteins, either directly or through effects on other systems that modulate their activity. ${ }^{34)}$ Therefore, the increase in the $\left[\mathrm{Ca}^{2+}\right]_{\mathrm{i}}$ may be a feature of the cytotoxicity induced by hydrogen peroxide. As described in Fig. 1 , hydrogen peroxide $(1 \mathrm{~mm})$ treatment induced cell death in about $30 \%$ of P388/DOX cells and this ratio was equal to that of P388/S cells treated with $0.3 \mathrm{~mm}$ of hydrogen peroxide. In addition, our results showed that a marked increase in the intracellular $\mathrm{Ca}^{2+}$ was observed in P388/S cells treated with hydrogen peroxide. But no change following hydrogen peroxide addition $(0.3-1 \mathrm{~mm})$ was observed in the resistant cells. These findings suggest that the intracellular $\mathrm{Ca}^{2+}$ is not involved directly in hydrogen peroxide (1 mM)-induced cell death in the resistant cells. Okazaki et al. ${ }^{35)}$ showed that hydrogen peroxide may increase the $\left[\mathrm{Ca}^{2+}\right]_{\mathrm{i}}$ through a mechanism related to the effects of hydrogen peroxide on the cellular nonprotein thiol. Accordingly, the elevated level of intracellular GSH in the resistant cells seems to reduce the amount of hydrogen peroxide-induced increase in the intracellular $\mathrm{Ca}^{2+}$.

The caspases, cysteine proteases, play a critical role during apoptosis. Hampton and Orrenius ${ }^{36)}$ recently demonstrated that hydrogen peroxide initially inhibits the caspases and delays apoptosis. Subsequently, depending on the degree of the initial oxidative stress, caspases are activated and the cells die by apoptosis. However, the mechanism by which hydrogen peroxide regulates caspase activity in the resistant cells is not clear as yet. Anuszewska et al. ${ }^{12)}$ have demonstrated that some cell lines exposed to nontoxic doses of hydrogen peroxide become less sensitive to the cytotoxic effect induced by a high dose of DOX. When hydrogen peroxide was exposed to cancer cells, the intracellular ROS generation in the resistant cells was lower than that in the parent cells. Similarly, a significant decrease in the intracellular ROS production induced by DOX treatment was found in the resistant cells. This fact is evidence of a property of the resistant cells. Hydrogen peroxide is known to convert quickly into hydroxyl radicals in cells, and it has cytotoxic activity which results from DNA damage, lipid peroxidation and biochemical perturbations such as cytoplasmic changes and gross perturbation of the cytoskeleton and plasma membrane in cells..$^{37,38)}$ Exogenous superoxide dismutase, catalase, and hydroxyl radical scavengers were shown to partially protect tumor cells from DOX cytotoxicity. ${ }^{9}$ It was also reported that the occurrence of an increase in these antioxidant enzyme activities is dependent in some way on inherent or acquired resistance. ${ }^{12,39)}$

In summary, we have shown that hydrogen peroxide markedly induced cell death in the parent cells, but has a slight effect on P-gp-overexpressing DOX-resistant cells. Hydrogen peroxide also increased $\mathrm{Ca}^{2+}$ influx in P388/S cells, but no change was observed following hydrogen peroxide addition in the resistant cells. Resistant cells also showed a more significant level of GSH compared to the sensitive cells. These findings suggest that the resistant cells have a strong protective ability against cell death caused by oxidative stress, and involve an increment of GSH.

\section{REFERENCES}

1) Ling V., Cancer, 69, 2603-2609 (1992).

2) Gottesman M. M., Pastan I., Annu. Rev. Biochem., 62, 385-427 (1993).

3) Aszalos A., Ross D. D., Anticancer Res., 18, 2937-2944 (1998).

4) Bradshaw D. M., Arceci R. J., J. Clin. Oncol., 16, $674-690$ (1998).

5) Lo A., Burckart G. J., J. Clin. Pharmacol., 9, 995-1005 (1999).

6) Lennon S. V., Martin S. J., Cotter T. G., Cell Prolif., 24, 203-214 (1991).

7) Dypbukt J. M., Ankarcrona M., Burkitt M., Sjoholm A., Strom K., Orrenius S., Nicotera P., J. Biol. Chem., 269, 30553-30560 (1994).

8) Doroshow J. H., Proc. Natl., Acad. Sci. U.S.A., 83, 4514-4518 (1986).

9) Jacobson M. D., Trends Biochem. Sci., 21, 83-86 (1996).

10) Muller I., Niethammer D., Bruchelt G., Int. J. Mol. Med., 1, 491-494 (1998).

11) Ravid A., Rocker D., Machlenkin A., Rotem C., Hochman A., KesslerIcekson G., Liberman U. A., Koren R., Cancer Res., 59, 862-867 (1999).

12) Anuszewska E. L., Gruber B. M., Koziorowska J. H., Biochem. Pharmacol., 54, 597-603 (1997).

13) Godard T., Deslandes E., Lebailly P., Vigreux C., Poulain L., Sichel F., Poul J. M., Gauduchon P., Cytometry, 36, 117-122 (1999).

14) Rijkers G. T., Justement L. B., Griffioen A. W., Cambier J. C., Cytometry, 11, 923-927 (1990).

15) Hasmann M., Valet G. K., Tapiero H., Trevorrow K., Lampidis T., Biochem. Pharmacol., 38, 305-312 (1989).

16) Tagliabue G., Pifferi A., Balconi G., Mascellani E., Geroni C., D'Incalci M., Ubezio P., Int. J. Cancer, 54, 435-442 (1993).

17) Tietze F., Anal. Biochem., 27, 502-522 (1969).

18) Smith P. K., Krohn R. I., Hermanson G. T., Mallia A. K., Gartner F. H., Provenzano M. D., Fujimoto E. K., Goeke N. M., Olson B. J., Klenk D. C., Anal. Biochem., 150, 76-85 (1985).

19) Miyajima A., Nakashima J., Yoshioka K., Tachibana M., Tazaki H., Murai M., Br. J. Cancer, 76, 206-210 (1997).

20) Suzuki Y. J., Forman H. J., Sevanian A., Free Radic. Biol. Med., 22, 269-285 (1997). 
21) Gewirtz D. A., Biochem. Pharmacol., 57, 727-741 (1999).

22) van Brussel J. P., van Steenbrugge G. J., Romijn J. C., Schroder F. H., Mickisch G. H., Eur. J. Cancer, 35, 664-671 (1999).

23) Wada H., Saikawa Y., Niida Y., Nishimura R., Noguchi T., Matsukawa H., Ichihara T., Koizumi S., Exp. Hematol., 27, 99-109 (1999).

24) Fujimura T., Shindo N., Murayama K., Furusawa S., Sasaki K., Takayanagi M., Takayanagi Y., Annu. Rep. Tohoku Coll. Pharm., 44, 225-230 (1997).

25) Shindo N., Fujimura T., Nojima-Kazuno S., Mineki R., Furusawa S., Sasaki K., Murayama K., Anal. Biochem., 264, 251-258 (1998).

26) Fukuoka K., Takeda M., Kobayashi M., Osaki T., Shirato I., Soejima A., Nagasawa T., Endou H., Life Sci., 62, 1125-1138 (1998).

27) Cook S. A., Sugden P. H., Clerk A., Circ. Res., 85, 940-949 (1999).

28) Li P. F., Dietz R., von Harsdorf R., EMBO J., 18, 6027-6036 (1999).

29) Simizu S., Imoto M., Masuda N., Takada M., Umezawa K., Cancer Res., 56, 4978-4982 (1996).

30) O’Brien M., Kruh G. D., Tew K. D., J. Pharmacol. Exp. Ther, 294, $480-487$ (2000).
31) van der Kolk D. M., Vellenga E., Muller M., de Vries E. G., Adv. Exp. Med. Biol., 457, 187-198 (1999).

32) Nicotera P., McConkey D., Svensson S. A., Bellomo G., Orrenius S., Toxicol., 52, 55-63 (1988).

33) Mirabelli F., Salis A., Vairetti M., Bellomo G., Thor H., Orrenius S., Arch. Biochem. Biophys., 270, 478-488 (1989).

34) Thomas G. P., Sims S. M., Cook M. A., Karmazyn M., J. Pharmacol. Exp. Ther, 286, 1208-1214 (1998).

35) Okazaki E., Chikahisa L., Kanemaru K., Oyama Y., Jpn. J. Pharmacol., 71, 273-280 (1996).

36) Hampton M. B., Orrenius S., FEBS Lett., 414, 552-556 (1997).

37) Welsh M. J., Shasby D. M., Husted R. M., J. Clin. Invest., 76, $1155-$ 1168 (1985).

38) Yang C. F., Shen H. M., Ong C. N., Biochem. Pharmacol., 57, 273279 (1999).

39) Mimnaugh E. G., Dusre L., Atwell J., Myers C. E., Cancer Res., 49, $8-15$ (1989). 